\title{
PELAJAR GENERASI PERTAMA SEBAGAI SUMBER MANUSIA: MOTIVASI DAN ASPIRASI MELANJUTKAN PELAJARAN KE INSTITUSI PENGAJIAN TINGGI (IPT)
}

\author{
FIRST GENERATION STUDENTS AS HUMAN \\ RESOURCE: MOTIVATION AND ASPIRATION TO \\ FURTHER STUDIES IN HIGHER EDUCATION \\ INSTITUTIONS
}

\author{
Abdul Hamid Abdul Rahim¹, Norzaini Azman \& \\ Rohaty@Norhatiah Mohd. Majzub \\ Fakulti Pendidikan \\ Universiti Kebangsaan Malaysia
}

${ }^{1}$ Corresponding author:mid1160@yahoo.com

\begin{abstract}
ABSTRAK
Tujuan - Memahami aspirasi pendidikan adalah sangat penting memandangkan keinginan seseorang untuk melanjutkan pelajaran adalah langkah awal dalam proses permohonan melanjutkan pelajaran ke IPT. Tujuan kajian ini dijalankan adalah untuk mengkaji fenomena motivasi dan aspirasi pelajar generasi pertama di sekolah menengah luar bandar. Secara khusus, kajian ini mengenal pasti tahap motivasi dan aspirasi pelajar generasi pertama untuk melanjutkan pelajaran ke IPT. Kajian ini turut melihat hubungan antara faktor motivasi dan aspirasi. Di samping melihat apakah faktor-faktor motivasi yang mempengaruhi aspirasi melanjutkan pelajaran ke IPT.
\end{abstract}

Metodologi - Kajian ini dijalankan dengan menggunakan gabungan pendekatan kuantitatif dan kualitatif. Seramai 417 pelajar generasi pertama yang sedang menuntut di tingkatan empat telah dipilih secara rawak berstrata sebagai responden untuk menjawab satu set soal selidik. Manakala 8 kumpulan berfokus telah dipilih melalui pensampelan bertujuan untuk ditemu bual bagi mendapatkan data kualitatif.

Dapatan - Hasil kajian menunjukkan motivasi pelajar generasi pertama luar bandar adalah pada tahap tinggi, manakala aspirasi mereka pada tahap sederhana tinggi. Terdapat hubungan yang positif 
dan signifikan di antara motivasi dan aspirasi. Faktor-faktor motivasi yang mempengaruhi aspirasi mencakupi faktor keperluan fisiologi, keperluan keselamatan, keperluan sosial, keperluan penghargaan kendiri dan keperluan penyempurnaan kendiri.

Kepentingan - Hasil kajian ini memberi implikasi strategik kepada pihak sekolah dan institusi pengajian tinggi (IPT) dalam usaha membantu pelajar generasi pertama di sekolah menengah luar bandar merealisasikan aspirasi mereka.

Kata kunci: Pelajar generasi pertama, tahap motivasi, tahap aspirasi, pendidikan tinggi

\section{ABSTRACT}

Purpose - Understanding educational aspirations is crucial because developing a desire to attend college is the first step in the application process into higher education institutions. The purpose of this study is to investigate aspects of motivation and aspiration of first-generation students at rural secondary schools. In particular, this study identifies the level of motivation and aspirations of firstgeneration students to pursue studies at higher education institutions. The study also examines the relationship between motivation and aspirations and the motivational factors that influence aspirations.

Design - The study used an explanatory mixed method approach. 417 of form four first generation students were chosen by stratified random sampling to answer a set of questionnaires. Eight focused groups were chosen through a purposive sampling process to gather qualitative data.

Findings - Results of the study show that the level of first generation students' motivation is high while their aspirations were medium to high. There is a significantly positive relationship between motivation and aspiration. The motivational factors that influence aspirations include physiological needs, safety needs, social needs, esteem needs and self actualization needs.

Significance - The study has strategic implications on schools and higher education institutions in their efforts to aid rural area first generation students to realise their aspirations. 
Keywords: First-generation students, level of motivation, level of aspiration, higher education

\section{PENGENALAN}

Pendidikan tertiari merupakan pemangkin utama penjanaan sumber tenaga manusia yang berpengetahuan, berkemahiran, dan berketerampilan bagi memenuhi keperluan mencapai wawasan negara. Di Malaysia adalah dijangkakan sumber manusia yang berpendidikan tinggi sangat diperlukan dalam pasaran kerja pada masa akan datang (Kementerian Pengajian Tinggi 2008). Sebagai contoh, Jadual 1 menunjukkan pada tahun 2015 jumlah tenaga kerja berpendidikan tertiari adalah seramai 3,991.7 orang atau 30 peratus daripada keseluruhan tenaga kerja. Bilangan ini dijangka meningkat kepada 4,804.8 orang atau 33 peratus pada tahun 2020 .

Jadual 1

Jumlah Tenaga Kerja Berpendidikan Tertiari di Malaysia bagi Tempoh 20

\begin{tabular}{lcccc}
\hline Tahun & $\begin{array}{c}\text { Jumlah } \\
\text { Penduduk }\end{array}$ & $\begin{array}{c}\text { Jumlah Tenaga } \\
\text { kerja }\end{array}$ & $\begin{array}{c}\text { Jumlah } \\
\text { Pendidikan } \\
\text { Tertiari }\end{array}$ & Peratus \\
\hline 2015 & $31,786.1$ & $13,447.5$ & $3,991.7$ & 30 \\
2020 & $34,751.7$ & $14,560.1$ & $4,804.8$ & 33 \\
\hline
\end{tabular}

Sumber: Kementerian Pengajian Tinggi Malaysia, (2008).

Pertambahan bilangan tenaga kerja berpendidikan tertiari sememangnya mendesak terutama dalam usaha memenuhi keperluan Model Baru Ekonomi Malaysia (MBE). Matlamat MBE adalah untuk menjadikan Malaysia sebuah negara maju yang berpendapatan tinggi. Salah satu cara untuk mencapai matlamat tersebut memerlukan lebih ramai sumber tenaga manusia yang berpendidikan tertiari. Hal ini kerana dengan kelulusan akademik yang tinggi lazimnya seseorang itu dibayar upah atau gaji yang tinggi. Oleh sebab itu, tidak hairan jika didapati permintaan pelajar ke peringkat pendidikan tertiari atau ke IPT meningkat setiap tahun (Kementerian Pengajian Tinggi Malaysia, 2008). Namun di sebalik peningkatan permintaan tersebut berdasarkan kategori sekolah bandar dan luar bandar 
didapati pada sesi kemasukan 2008/2009 kadar kemasukan pelajar lepasan SPM sekolah luar bandar ke IPT masih rendah (18.2\%) berbanding pelajar di bandar (21.6\%) (Jabatan Pengajian Pengajian Tinggi, 2009). Fenomena ini sudah tentu boleh membantutkan usaha meluaskan akses dan meningkatkan ekuiti kemasukan ke IPT khususnya dalam kalangan pelajar generasi pertama di sekolah luar bandar. Mereka dikatakan berisiko tercicir daripada melanjutkan pelajaran ke pendidikan tertiari. Perkara ini berkait rapat dengan latar belakang mereka yang didapati mempunyai tahap aspirasi yang rendah (Saenz, Hurtado, Barrera, Wolf \& Yeung, 2007; Terenzini, Springer, Yaeger, Pascarella \& Nora, 1996; Terenzini, Cabrera \& Bernal, 2001) dan berstatus sosioekonomi rendah (Ceja, 2001; Peters, 2009). Ini bermakna mengharapkan pelajar generasi pertama sebagai sumber manusia yang berpengetahuan, berkemahiran dan berketrampilan pada masa akan datang sukar menjadi kenyataan. Justeru, timbul persoalan: apakah faktor yang mendorong pelajar generasi pertama untuk melanjutkan pelajaran ke IPT? Agak sukar menjawab persoalan tersebut secara empirikal kerana Freeman (2005) menyatakan kajian berkaitan dengan motivasi kendiri untuk melanjutkan pelajaran ke kolej masih kurang mendapat perhatian daripada pengkaji-pengkaji. Di Asia pada realitinya, amat sedikit maklumat berkaitan motivasi dan persepsi terhadap persekitaran pembelajaran (termasuklah pengaruh ibu bapa, rakan sebaya dan guru) (Mcinerney, 2006). Sehubungan itu, di Malaysia walaupun terdapat kajian berkaitan motivasi dalam bidang pendidikan, namun rata-rata ia dihubungkan dengan pencapaian (Zaharah, 2009; Zuaini, Nor Aziah \& Rosliza, 2008; Saemah, 2004, Mohd Firdaus, 2003), dan pengajaran serta pembelajaran (Noor Fitriyati, 2009; Halimah, 2006). Kajian berkaitan faktor mendorong pelajar untuk melanjutkan pelajaran ke IPT khususnya dalam kalangan pelajar sekolah luar bandar masih kurang. Oleh itu, dengan berlandaskan Teori Hierarki Keperluan Maslow (1970), kajian ini dijalankan bagi mengenal pasti sejauh mana faktor motivasi mempengaruhi aspirasi pelajar generasi pertama di sekolah menengah luar bandar.

Beberapa konsep penting yang digunakan dalam kajian ini memerlukan penjelasan lanjut. Penjelasan diperlukan khususnya dari segi definisi operasional untuk menjelaskan maksud istilah tersebut dalam konteks kajian ini. Definisi konsep tersebut adalah seperti berikut: 
1. Pelajar generasi pertama - Merujuk kepada pelajar yang tahap pendidikan ibu bapanya setakat sekolah menengah sahaja (York-Anderson \& Bowman, 1991; Horn \& Nunez, 2000; Choy, 2001; Ishitani, 2003). Dalam kajian ini pelajar generasi pertama merujuk kepada pelajar sekolah menengah yang mana ibu bapa pelajar berkenaan tidak atau pernah bersekolah tetapi sehingga peringkat sekolah menengah sahaja.

2. Motivasi - Dalam kajian ini motivasi merujuk kepada dorongan iaitu faktor-faktor yang mendorong pelajar generasi pertama untuk melanjutkan pelajaran ke IPT yang mencakupi faktor keperluan fisiologi, keperluan keselamatan, keperluan sosial, keperluan penghargaan kendiri dan keperluan penyempurnaan kendiri.

3. Aspirasi - aspirasi dalam kajian ini merujuk kepada keinginan pelajar untuk melanjutkan pelajaran ke IPT yang mencakupi aspek matlamat dan kesediaan.

\section{SOROTAN KAJIAN}

\section{Faktor Motivasi dan Aspirasi}

Sheek (2007) mencadangkan adalah penting untuk mengkaji apakah faktor-faktor yang memotivasikan pelajar untuk merealisasikan aspirasi mereka. Kajian perlu dilakukan selaras dengan pandangan Norliza (2011) bahawa keperluan yang telah dipenuhi bukanlah suatu pendorong kepada motivasi seseorang. Hal ini bermakna motivasi dan minat berperanan menentukan hala tuju dan matlamat seseorang (Syed Mohamad, 2010). Berdasarkan hasil tinjauan literatur, didapati aspirasi pelajar untuk melanjutkan pelajaran ke kolej atau universiti adalah berhubungan secara positif dengan faktor motivasi khususnya dorongan untuk memenuhi keperluan peribadi (Sheek, 2007; Pope \& Fermin, 2003; Freeman, 1999; Burnell, 2003) dan juga keperluan keluarga (Saenz et al., 2007; Smith, 2009; Gofen 2009; Smith, 2008). Pendidikan dianggap berguna dan penting untuk memenuhi keperluan fisiologi, keperluan keselamatan dan penyempurnaan kendiri pelajar dan keluarga mereka.

Merujuk kepada motif untuk membantu keluarga, kebanyakan kajian menunjukkan pelajar ingin melanjutkan pelajaran ke IPT untuk memenuhi keperluan fisiologi. Keperluan fisiologi antara lain 
adalah untuk memenuhi keperluan memperbaiki taraf hidup dan membantu keluarga keluar dari belenggu kemiskinan. Hasil kajian Saenz et al. (2007) terhadap pelajar generasi pertama mendapati peluang yang diberikan oleh ibu bapa mereka untuk melanjutkan pelajaran ke kolej adalah untuk memperbaiki taraf hidup keluarga. Dalam hal ini pertimbangan membantu kewangan keluarga khususnya memperoleh pendapatan pada masa depan adalah pemberi motivasi yang kuat kepada mereka untuk melanjutkan pelajaran ke kolej. Menurut Engle, Bormeo dan O'Brien (2006), pelajar generasi pertama tidak menganggap melanjutkan pelajaran ke kolej itu sebagai usaha peribadi, tetapi lebih kepada sebagai hasil usaha generasi mereka untuk kemajuan keluarga dan masyarakat.

Penemuan kajian ini selari dengan hasil kajian oleh Gofen (2009) yang mendapati bahawa pelajar ingin melanjutkan pelajaran ke IPT kerana ingin membantu keluarga keluar dari belenggu kemiskinan. Berdasarkan data temubual, terdapat responden yang meluahkan isi hati ibu bapa mereka dengan berkata: "jangan seperti kami..."(Engle, Bormeo \& O'Brien, 2006). Ini bermakna responden percaya bahawa pendidikan bukan sahaja sesuatu yang bernilai dalam kehidupan, tetapi juga sebagai salah satu cara keluar daripada belenggu kemiskinan.

Kajian oleh Smith (2008) terhadap pelajar perempuan kulit hitam sebagai pelajar generasi pertama mendapati pelajar ingin memperoleh ijazah untuk meningkatkan mobiliti sosial. Di samping itu, ia juga sebagai salah satu cara untuk keluar daripada belenggu kemiskinan. Ibu bapa mereka percaya bahawa matlamat untuk memperoleh diploma akan membantu anak mereka untuk menjadi pekerja yang berkemahiran. Perkara yang sama turut diperoleh dalam hasil kajian Smith (2009) yang mendapati masyarakat Afrikan Amerikan ingin memperoleh diploma daripada kolej atau universiti sebagai cara untuk mobiliti sosial dan keluar daripada belenggu kemiskinan.

Hasil kajian oleh Jui-Mei Yein (2004) terhadap 408 orang pengedar barangan Amway mendapati mereka ingin melanjutkan pelajaran kerana ingin memenuhi pelbagai keperluan mencakupi keperluan fisiologi, keselamatan, sosial, estim kendiri dan penyempurnaan kendiri. Justeru, tidak hairan jika beberapa kajian lepas telah menunjukkan faktor motivasi sebagai pendorong kepada pelajar untuk melanjutkan pelajaran ke kolej atau universiti bukan 
sekadar untuk memenuhi keperluan fisiologi, tetapi juga keperluan penghargaan kendiri, keperluan keselamatan dan penyempurnaan kendiri. Antara faktor yang berkait dengan keperluan tersebut adalah keinginan memenuhi matlamat peribadi dan kerjaya (Pope \& Fermin, 2003) serta ingin disanjung (Sheek, 2007). Kajian Sheek (2007) mendapati bahawa pelajar ingin melanjutkan pelajaran ke IPT kerana ingin disanjung oleh orang lain khususnya ibu bapa. Dalam hal ini hasil kajian beliau mendapati pelajar ingin ibu bapa berbangga dengan mereka. Dapatan kajian ini secara tidak langsung menunjukkan terdapat hubungan yang positif antara aspirasi dan motivasi khususnya untuk memenuhi keperluan penghargaan kendiri pelajar.

Kajian oleh Pope dan Fermin (2003) pula mendapati alasan asas pelajar untuk melanjutkan pelajaran ke kolej atau universiti adalah untuk mencapai matlamat peribadi dan kerjaya. Matlamat peribadi pelajar adalah untuk memperoleh ijazah. Manakala alasan untuk memperoleh peluang pekerjaan yang lebih baik selepas memperoleh ijazah merupakan alasan terpenting yang mendorong pelajar untuk melanjutkan pelajaran. Ini bermakna pelajar ingin melanjutkan pelajaran ke IPT berkait rapat dengan dorongan untuk memenuhi keperluan penyempurnaan kendiri. Dapatan ini selari dengan hasil kajian oleh Chwan-Yi Chiang (2001) yang menyatakan disebabkan ingin memenuhi keperluan penyempurnaan kendiri, pelajar ingin melanjutkan ke IPT. Sungguhpun begitu, kajian oleh Freeman (1999) pula mendapati pertimbangan penting pelajar untuk melanjutkan pelajaran ke IPT adalah jangkaan mereka memperoleh pekerjaan yang terjamin selepas tamat pengajian kelak. Perkara ini tidak menghairankan kerana bagi diri pelajar, pencapaian akademik yang tinggi melambangkan penguasaan ilmu pengetahuan bagi mencapai matlamat dalam kerjaya dan kehidupan mereka (Lim \& Tang, 2005). Dapatan ini bermakna pelajar hanya akan melanjutkan pelajaran ke IPT jika mereka merasakan tindakan tersebut menjamin kehidupan yang lebih baik pada masa akan datang. Dengan kata lain, aspirasi pelajar melanjutkan pelajaran ke IPT adalah berhubungan secara positif dengan motivasi yang juga berkait rapat dengan keinginan memenuhi keperluan keselamatan mereka.

Walau bagaimanapun, terdapat beberapa kajian yang menunjukkan pelajar tidak bermotivasi dan beraspirasi untuk melanjutkan pelajaran ke IPT. Hasil kajian Burnell (2003) mendapati tiada 
seorang pun daripada peserta yang telah melanjutkan pelajaran ke kolej selepas tamat sekolah menengah. Responden kajian berpendapat melanjutkan pelajaran ke kolej tidak menjanjikan kehidupan yang lebih baik pada masa akan datang. Pada pandangan peserta kajian "dunia sebenar" adalah bertentangan dengan dunia di kolej. "Dunia sebenar" merujuk kepada dunia pekerjaan yang bukan sahaja memiliki pendapatan yang terjamin, tetapi juga memiliki keluarga yang stabil dan berkesinambungan. Sebaliknya, mereka melihat dunia kolej sebagai membuang masa, usaha, wang dan berisiko (Burnell, 2003). Dapatan kajian ini jelas menunjukkan bahawa keputusan seseorang pelajar untuk melanjutkan pelajaran ke kolej atau universiti berkait rapat dengan dorongan keperluan fisiologi dan keselamatan. Pelajar tidak akan melanjutkan pelajaran ke kolej atau universiti jika mereka merasakan bahawa melanjutkan pelajaran tidak menjamin kehidupan yang lebih baik pada masa akan datang. Ini bermakna motivasi dan aspirasi untuk melanjutkan pelajaran ke kolej adalah berhubungan secara positif dan bergantung kepada nilai yang diberikan terhadap pendidikan (Phinney et al., 2006). Jika pendidikan tinggi dianggap dapat membantu untuk memenuhi pelbagai keperluan kendiri, maka seseorang pelajar akan bermotivasi sekaligus menjadi pendorong kepada aspirasi mereka untuk melanjutkan pelajaran ke IPT.

Merujuk kepada aspirasi pelajar generasi pertama, tinjauan literatur menunjukkan dapatan yang tidak muktamad. Terdapat kajian yang menunjukkan tahap aspirasi pelajar generasi pertama adalah rendah (Saenz et al., 2007) dan sebaliknya (Grieve, 2009). Kajian oleh Saenz et al. (2007) mendapati pelajar generasi pertama mempunyai tahap aspirasi pendidikan yang rendah berbanding dengan rakan pelajar bukan generasi pertama. Hasil kajian ini selari dengan hasil kajian Grieve (2009) yang mendapati pelajar bukan generasi pertama khususnya pelajar lelaki di bandar mempunyai aspirasi yang tinggi untuk melanjutkan pelajaran ke IPT. Perbezaan ini berlaku disebabkan pelajar generasi pertama kekurangan maklumat berkenaan ijazah, perkembangan di kolej dan kurangnya persediaan akademik.

Hasil kajian lepas mengenai tahap aspirasi pelajar generasi pertama juga tidak konsisten. Kajian Horn dan Nunez (2000) mendapati pada awalnya (1988) iaitu semasa peringkat gred ke- 8, tahap aspirasi pendidikan pelajar berada pada tahap tinggi iaitu $42 \%$ beraspirasi 
untuk melanjutkan pelajaran ke peringkat ijazah pertama dan $13 \%$ beraspirasi untuk melanjutkan sehingga peringkat ijazah lanjutan. Bagaimanapun, kajian lanjutan yang dilakukan mendapati keadaannya berubah apabila pelajar yang ingin mencapai tahap pendidikan ijazah sarjana muda telah menurun daripada $42 \%$ kepada $29 \%$ sahaja.

Kesimpulannya, tinjauan literatur menunjukkan aspirasi pelajar generasi pertama masih tidak konklusif. Sehubungan itu, terdapat keperluan supaya diadakan kajian lanjutan. Di samping itu, adalah jelas bahawa pelajar ingin melanjutkan pelajaran ke IPT kerana dorongan beberapa faktor motivasi. Pelajar generasi pertama didapati bertindak melanjutkan pelajaran ke IPT jika mereka merasakan tindakan tersebut dapat memenuhi keperluan diri dan keluarga mereka. Fenomena ini selaras dengan pandangan Maslow (1970) bahawa tingkah laku manusia digerakkan oleh keperluannya yang mencakupi keperluan fisiologi, keselamatan, keperluan sosial, penghargaan kendiri dan penyempurnaan kendiri.

\section{TUJUAN KAJIAN}

Kajian ini bertujuan untuk mengenal pasti tahap motivasi dan aspirasi dalam kalangan pelajar generasi pertama di sekolah menengah luar bandar. Kajian ini juga turut melihat hubungan antara faktor motivasi dan aspirasi. Kajian ini seterusnya ingin meneliti sejauh mana faktor-faktor motivasi mempengaruhi aspirasi melanjutkan pelajaran ke IPT.

\section{PERSOALAN DAN HIPOTESIS KAJIAN}

Secara khusus kajian ini cuba menjawab persoalan berikut:

1. Apakah tahap motivasi dan aspirasi pelajar generasi pertama untuk melanjutkan pelajaran ke IPT?

2. Adakah terdapat hubungan antara motivasi dengan aspirasi pelajar generasi pertama?

3. Apakah faktor motivasi yang mempengaruhi aspirasi pelajar generasi pertama untuk melanjutkan pelajaran ke IPT? 
Sehubungan itu, hipotesis nol telah dibentuk untuk menjawab persoalan kajian yang kedua iaitu: Tidak terdapat hubungan yang signifikan antara motivasi dengan aspirasi pelajar generasi pertama.

\section{METODOLOGI}

Kajian ini menggunakan kaedah gabungan (explanatory mixed method) iaitu gabungan pendekatan kuantitatif dan kualitatif (Creswell \& Plano Clark, 2011). Melalui kaedah ini, data kuantitatif digunakan sebagai asas untuk mendapat gambaran umum tentang tahap motivasi, aspirasi dan hubungan antara motivasi dan aspirasi pelajar generasi pertama di sekolah menengah luar bandar. Manakala data kualitatif digunakan sebagai data tambahan untuk mendapatkan penjelasan lanjut sekali gus mengukuhkan hasil dapatan kajian kuantitatif. Secara khusus, data kuantitatif digunakan untuk menerangkan dengan lebih mendalam berkaitan tahap motivasi, aspirasi dan sejauh mana faktor-faktor motivasi mempengaruhi aspirasi.

\section{Populasi dan Sampel}

Populasi kajian adalah pelajargenerasi pertama yang sedang menuntut di tingkatan 4 di sekolah menengah luar bandar di bahagian Tawau negeri Sabah. Seramai 417 orang pelajar telah dipilih secara rawak berlapis sebagai sampel kajian daripada lapan buah sekolah yang terletak di pinggir bandar, perkampungan tradisional, penempatan terancang (Felda) dan di pedalaman (pulau). Manakala 8 kumpulan berfokus dengan setiap kumpulan berfokus terdiri daripada 6 orang pelajar telah dipilih sebagai peserta kajian untuk ditemu bual bagi mendapatkan data kualitatif. Pemilihan peserta kumpulan temubual berfokus dilakukan melalui teknik pensampelan bertujuan.

\section{Instrumen}

Kajian ini menggunakan dua set instrumen iaitu soal selidik dan protokol temu bual. Satu set soal selidik yang terdiri daripada bahagian motivasi dan aspirasi telah digunakan bagi pengumpulan 
data kajian kuantitatif. Soal selidik bahagian motivasi terdiri daripada 25 item yang diperoleh hasil adaptasi daripada soal selidik Jui-Mei Yien (2004) dan Chwan-Yi Chiang (2001). Manakala soal selidik bahagian aspirasi terdiri daripada 10 item hasil adaptasi daripada soal selidik Grieve (2009). Semua item soal selidik tersebut mengkehendaki pelajar memberi maklum balas terhadap pernyataan yang disediakan berdasarkan skala likert yang terdiri daripada tahap 1 = sangat tidak setuju sehingga tahap 5 = sangat setuju.

Seterusnya, satu set protokol temu bual digunakan bagi mendapatkan data kualitatif daripada 8 kumpulan berfokus. Set protokol temu bual tersebut dibina sendiri oleh pengkaji berpandukan konstruk dan item-item soal selidik motivasi dan aspirasi. Ia terdiri daripada dua bahagian utama. Bahagian pertama adalah aspek aspirasi yang mengandung soalan seperti 'Apakah perancangan anda selepas tamat belajar tingkatan 5 iaitu setelah memperoleh keputusan SPM?' dan 'Apakah tahap pendidikan tertinggi yang ingin anda capai?' Manakala bahagian kedua adalah berkaitan aspek motivasi yang mengandungi soalan antara lain:'Apakah pandangan anda tentang usaha anda melanjutkan pelajaran ke IPT untuk memperoleh kehidupan yang lebih terjamin pada masa depan?' dan 'Sejauh manakah belajar ke IPT dapat memenuhi impian dan mencapai cita-cita anda?' Setiap temu bual yang dijalankan ke atas kumpulan berfokus telah mengambil masa lebih kurang 1 hingga 2 jam.

\section{Analisis Data}

Data kajian yang diperoleh daripada set soal selidik dianalisis menggunakan perisian Statistical Package for Social Science (SPSS) versi 16.0. Kaedah analisis data yang digunakan iaitu kaedah statistik deskriptif (min dan sisihan piawai) dan statistik inferensi (korelasi pearson). Statistik deskriptif iaitu skor min digunakan untuk menerangkan tahap motivasi dan aspirasi aspirasi pelajar generasi pertama. Di samping itu, ia juga berguna untuk menerangkan faktor-faktor motivasi yang mempengaruhi aspirasi. Untuk tujuan tersebut, pengkaji menggunakan interpretasi skor min yang telah digunakan oleh Nunnaly dan Bernstein (1994) seperti ditunjukkan pada Jadual 2. 
Jadual 2

Interpretasi Skor

\begin{tabular}{cc}
\hline Skor Min & Interpretasi Skor Min \\
\hline $1.00-2.00$ & Rendah \\
$2.01-3.00$ & Sederhana rendah \\
$3.01-4.00$ & Sederhana tinggi \\
$4.01-5.00$ & Tinggi \\
\hline
\end{tabular}

Sumber: Nunnaly \& Bernstein, (1994).

Manakala statistik inferensi, khususnya korelasi Pearson digunakan untuk menerangkan hubungan antara faktor motivasi dan aspirasi pelajar generasi pertama. Bagi mentafsirkan kekuatan hubungan antara pemboleh ubah yang dikaji, pengkaji menggunakan cadangan Joseph et al. (1997) iaitu bawah 0.10 (lemah); 0.10-0.30 (sederhana) dan 0.30 ke atas (kuat). Dalam pada itu, tanda pada pekali korelasi itu boleh jadi bertanda positif (+) atau negatif (-). Jika pekali korelasi bernilai positif bermaksud hubungan satu pemboleh ubah adalah berkadar terus dengan satu pemboleh ubah yang lain. Sebaliknya, jika pekali korelasi bernilai negatif, bermakna bahawa hubungan antara dua pemboleh ubah adalah berkadar songsang (Azizi, Shahrin, Jamaludin, Yusof \& Abdul Rahim, 2007). Arah yang songsang berlaku apabila pertambahan nilai pada sesuatu pemboleh ubah berkait dengan pengurangan nilai pada pemboleh ubah yang lain. Sementara itu, data kualitatif dalam konteks kajian ini dianalisis secara manual dengan cara membentuk tema-tema yang dapat menyokong dan menerangkan lebih lanjut dapatan kajian kuantitatif.Hal yang demikian dilakukan selari dengan pandangan Patton (1990) bahawa tiada satu peraturan yang rigid dalam penganalisisan data kualitatif.

\section{HASIL KAJIAN}

\section{Tahap Motivasi dan Tahap Aspirasi Pelajar Generasi Pertama}

Jadual 3 menunjukkan min keseluruhan motivasi pelajar generasi pertama adalah 4.35. Dapatan ini menunjukkan bahawa motivasi pelajar generasi pertama adalah pada tahap tinggi. Komponen motivasi terpenting yang mendorong pelajar untuk berbuat demikian adalah aspek keperluan fisiologi $(\mathrm{m}=4.63)$. Dapatan ini bermakna 
pelajar ingin melanjutkan pelajaran ke IPT bagi memenuhi keperluan fisiologi mereka seperti mendapatkan pekerjaan yang lebih baik selepas tamat pengajian. Komponen motivasi kedua tertinggi adalah aspek keperluan keselamatan $(\mathrm{m}=4.51)$ dan keperluan penghargaan kendiri $(m=4.51)$. Seterusnya, pelajar juga ingin melanjutkan pelajaran ke IPT bagi memenuhi keperluan penyempurnaan kendiri $(\mathrm{m}=4.30)$ dan keperluan sosial $(\mathrm{m}=3.87)$.

\section{Jadual 3}

Tahap Motivasi Pelajar Generasi Pertama di Sekolah Menengah Luar Bandar di Sabah

\begin{tabular}{lcc}
\hline \multicolumn{1}{c}{ Komponen Motivasi } & Min & Sisihan Piawai \\
\hline Keperluan fisiologi & 4.63 & 0.33 \\
Keperluan keselamatan & 4.51 & 0.42 \\
Keperluan sosial & 3.87 & 0.66 \\
Keperluan penghargaan kendiri & 4.51 & 0.40 \\
Keperluan penyempurnaan kendiri & 4.30 & 0.41 \\
Keseluruhan Motivasi & $\mathbf{4 . 3 5}$ & $\mathbf{0 . 3 3}$ \\
\hline
\end{tabular}

Jadual 4 menunjukkan min keseluruhan aspirasi pelajar generasi pertama adalah 3.86. Dapatan ini menunjukkan bahawa aspirasi pelajar generasi pertama adalah pada tahap sederhana tinggi. Fenomena aspirasi pelajar generasi pertama dapat diperhatikan dengan lebih lanjut pada matlamat dan kesediaan mereka. Pelajar mempunyai matlamat yang jelas $(\mathrm{m}=4.14)$ untuk melanjutkan pelajaran ke IPT. Dapatan ini disokong oleh hasil temu bual seperti berikut:

Saya memang ada perancangan dan punya cita-cita untuk melanjutkan pelajaran ke matrikulasi dan belajar sungguh-sungguh dan terus lagi IPT (P39). Perancangan saya selepas SPM saya akan masuk tingkatan enam, selepas STPM baru masuk IPTA (P16).

Pelajar generasi pertama juga menunjukkan kesediaan yang sederhana tinggi $(m=3.67)$ untuk melanjutkan pelajaran ke IPT (Jadual 4). Dalam kajian ini kesediaan merujuk kepada kesanggupan pelajar untuk melakukan sesuatu yang positif bagi merealisasikan aspirasi mereka. Sehubungan itu, hasil dapatan temu bual dengan kumpulan berfokus mendapati pelajar menunjukkan kesediaan 
mengikuti kursus bahasa Inggeris dan mendapatkan pinjaman kewangan bagi membiayai kos pengajian mereka. Dapatan temu bual menggambarkan perkara tersebut.

Saya rasa saya akan ambil kursus bahasa Inggeris di sebabkan bahasa Inggeris saya agak teruk, kalau di IPT banyak menggunakan bahasa Inggeris tu lah saya bercadang untuk mengambil kursus Inggeris (P28).

Untuk melanjutkan pelajaran saya sanggup meminjam sebab saya ini dari kampung, orang miskin dan tidak mampu untuk membayar, sebab ke IPT ini banyak keperluannya (P38).

Jadual 4

Tahap Aspirasi Pelajar Generasi Pertama di Sekolah Menengah Luar Bandar

\begin{tabular}{lcc}
\hline \multicolumn{1}{c}{ Komponen Aspirasi } & Min & Sisihan Piawai \\
\hline Matlamat & 4.14 & 0.56 \\
Kesediaan pelajar & 3.67 & 0.55 \\
Keseluruhan Aspirasi & $\mathbf{3 . 8 6}$ & $\mathbf{0 . 4 6}$ \\
\hline
\end{tabular}

\section{hubungan Motivasi dan Aspirasi}

Jadual 5 menunjukkan keputusan ujian korelasi pearson bagi melihat hubungan antara faktor motivasi secara keseluruhan dengan aspirasi dalam kalangan pelajar generasi pertama di sekolah menengah luar bandar.

\section{Jadual 5}

Analisis Hubungan antara Faktor Motivasi dengan Aspirasi Pelajar Generasi Pertama di Sekolah Menengah Luar Bandar

\begin{tabular}{lcc}
\hline Aspirasi & r & Sig. - p \\
Motivasi & .30 & $0.000 *$ \\
secara keseluruhan & & \\
\hline
\end{tabular}

* Sginifikan pada paras 0.05, 2 hujung

Hasil analisis data menunjukkan nilai korelasi ialah $\mathrm{r}=0.30$. Keputusan analisis ini menunjukkan terdapat hubungan yang kuat dan signifikan antara motivasi dengan aspirasi dalam kalangan 
pelajar generasi pertama di sekolah menengah luar bandar. Ini bermakna responden yang tinggi skor motivasinya juga akan menunjukkan skor yang tinggi dalam aspirasi.

Jadual 6 menunjukkan secara lebih terperinci hubungan antara aspek-aspek motivasi dengan aspirasi dalam kalangan pelajar generasi pertama di sekolah menengah luar bandar.

Jadual 6

Analisis Hubungan antara Aspek-aspek Motivasi dengan Aspirasi Pelajar Generasi Pertama di Sekolah Menengah Luar Bandar

\begin{tabular}{lll}
\hline \multicolumn{1}{c}{$\begin{array}{c}\text { Aspek-aspek } \\
\text { Motivasi }\end{array}$} & R & Sig. - p \\
\hline Keperluan fisiologi & .25 & $0.000^{* *}$ \\
Keperluan keselamatan & .32 & $0.000^{* *}$ \\
Keperluan sosial & .17 & $0.000^{* *}$ \\
Keperluan penghargaan kendiri & .19 & $0.000^{* *}$ \\
Keperluan penyempurnaan kendiri & .19 & $0.000^{* *}$ \\
\hline
\end{tabular}

** Signifikan pada aras $0.01,2$ hujung

Dapatan kajian menunjukkan terdapat hubungan yang signifikan antara semua aspek motivasi dengan aspirasi dalam kalangan pelajar generasi pertama di sekolah menengah luar bandar. Bagaimanapun, hanya aspek keperluan keselamatan sahaja yang mempunyai hubungan kuat dengan aspirasi. Manakala keperluan fisiologi, keperluan sosial, keperluan penghargaan kendiri dan keperluan penyempurnaan kendiri menunjukkan hubungan dengan aspirasi pada tahap sederhana sahaja.

\section{Faktor-faktor Motivasi Mempengaruhi Aspirasi}

Hasil kajian kuantitatif dan kualitatif mendapati faktor motivasi mempengaruhi aspirasi pelajar generasi pertama. Faktorfaktor motivasi mencakupi aspek keperluan fisiologi, keperluan keselamatan, keperluan sosial, keperluan penghargaan kendiri dan keperluan penyempurnaan kendiri. Jadual 7 menunjukkan skor min bagi keseluruhan keperluan fisiologi ialah 4.63. Hal ini bermakna, aspek keperluan fisiologi merupakan faktor utama yang menjadi pendorong kepada pelajar untuk melanjutkan pelajaran ke IPT. Secara terperinci, faktor utama bagi aspek keperluan fisiologi yang menjadi pendorong kepada pelajar untuk melanjutkan pelajaran 
adalah untuk membantu keluarga mencapai taraf hidup lebih baik $(\min =4.83)$ dan mendapat pekerjaan yang lebih baik $(\min =4.83)$. Dapatan kajian kualitatif mengukuhkan dapatan tersebut seperti yang ditunjukkan oleh hasil temu bual seperti berikut:

Saya mahu punya pekerjaan yang baik untuk membantu dari segi kewangan keluarga kami dan sebagai saya anak sulung serta kakak kepada adik-adik saya, kalau kita punya pekerjaan yang baik akan mendapat gaji yang tinggi (P17).

Saya ingin melanjutkan pelajaran ke IPT sebab saya mahu dapat pekerjaan yang standard dan bergaji tinggi supaya dapat membantu keluarga dari segi kewangan (P22).

Faktor kedua terpenting adalah faktor keperluan keselamatan $(\mathrm{m}=4.51)$ dan keperluan penghargaan kendiri $(\mathrm{m}=4.51)$. Jadual 7 menunjukkan bagi aspek keperluan keselamatan, faktor penting adalah keinginan pelajar untuk menikmati kehidupan yang lebih terjamin pada masa depan $(\mathrm{m}=4.76)$ dan keperluan menjadi contoh yang baik kepada adik beradik yang lain $(\mathrm{m}=4.58)$ (Jadual 7$)$. Fenomena tersebut digambarkan dengan jelas oleh hasil dapatan temu bual.

Saya ingin melanjutkan pelajaran ke IPT sebab saya mahu punya masa depan yang cerah, ada pendapatan yang tetap dan menjadi contoh kepada adik-beradik yang lain (P7).

Saya ingin mengubah masa depan sebab sekarang kami hidup dalam susah so saya akan ubah untuk hidup senang ke masa depan nanti (P35).

Manakala bagi aspek keperluan penghargaan kendiri, faktor penting dan utama mempengaruhi aspirasi pelajar generasi pertama melanjutkan pelajaran ke IPT adalah untuk mendapatkan anugerah kecemerlangan akademik $(m=4.72)$. Di samping itu, pelajar juga didorong oleh faktor untuk mendapatkan ilmu pengetahuan $(\mathrm{m}=4.69)$ (jadual 6). Dapatan ini disokong oleh hasil dapatan temu bual seperti berikut:

Saya mahu sambung belajar kerana ingin menambahkan ilmu pengetahuan tentang bidang yang saya ambil.Ya lah, bidang sains (P6). 
Walaupun di sekolah saya tidak pernah mendapat anugerah, bila melanjutkan pelajaran saya ingin mendapat kecemerlangan di IPT nanti dan menjadi pelajar terbaik (P2).

Seterusnya, faktor yang mempengaruhi aspirasi pelajar generasi pertama untuk melanjutkan pelajaran ke IPT adalah aspek keperluan penyempurnaan kendiri $(\mathrm{m}=4.30)$. Bagi aspek tersebut, faktor yang dominan adalah berkait dengan keinginan memenuhi impian dan mencapai cita-cita peribadi (Jadual 7). Hal ini bermakna pelajar generasi pertama mahu melanjutkan pelajaran ke IPT kerana dorongan untuk memenuhi impian dan mencapai cita-cita peribadi. Perkara tersebut dijelaskan pada hasil temu bual seperti berikut:

Bagi saya masuk ke IPT tu satu cara untuk mencapai impian saya, contohnya saya dapat belajar bidang law, so di sana saya belajar tentang law so selepas tu saya boleh merealisasikan impian saya menjadi peguam (P27).

Saya ingin sambung belajar untuk mencapai cita-cita dan menunaikan janji kepada ibu bapa saya (P16).

Faktor terakhir adalah merujuk kepada aspek sosial $(m=3.87)$. Berdasarkan nilai skor min, aspek keperluan sosial menduduki tempat terakhir berbanding dengan aspek keperluan fisiologi, keperluan keselamatan, keperluan penghargaan kendiri dan keperluan penyempurnaan kendiri. Dapatan ini bermakna aspek keperluan sosial adalah kurang penting sebagai pendorong kepada pelajar untuk melanjutkan pelajaran ke IPT berbanding aspek-aspek yang lain dalam komponen faktor motivasi. Jadual 7 menunjukkan bagi aspek sosial, faktor utama adalah berkait dengan keinginan berjumpa lebih ramai kawan $(\mathrm{m}=4.06)$ dan keinginan menyertai pelbagai aktiviti persatuan $(\mathrm{m}=4.00)$. Dapatan temu bual menunjukkan bagi faktor keperluan sosial khususnya keinginan berjumpa lebih ramai kawan bukanlah faktor utama kepada pelajar generasi pertama untuk melanjutkan pelajaran ke IPT. Hasil temu bual memberi gambaran seperti berikut:

Saya masuk IPT untuk belajar, kalau mencari kawan ini di luar pun banyak, dia bukan satu alasan untuk masuk IPT (P24).

Kalau saya wajar untuk cari kawan untuk berkomunikasi, tapi itu faktor sampingan sahaja lebih utama untuk mencapai citacita dan untuk masa depan (P36). 


\section{Jadual 7}

Faktor Motivasi yang Mempengaruhi Aspirasi Melanjutkan Pelajaran ke IPT

\begin{tabular}{|c|c|c|}
\hline Item Motivasi & Min & $\begin{array}{l}\text { Sisihan } \\
\text { Piawai }\end{array}$ \\
\hline \multicolumn{3}{|l|}{ Keperluan fisiologi } \\
\hline Mendapatkan pekerjaan yang lebih baik & 4.83 & 0.41 \\
\hline Membeli keperluan makanan dan pakaian & 4.51 & 0.65 \\
\hline Membantu keluarga mencapai taraf hidup lebih baik & 4.83 & 0.40 \\
\hline Pelajaran dan melanjutkan pelajaran adalah penting & 4.58 & 0.57 \\
\hline Mendapatkan pekerjaan bergaji tinggi & 4.43 & 0.67 \\
\hline Keseluruhan Keperluan Fisiologi & 4.63 & 0.33 \\
\hline \multicolumn{3}{|l|}{ Keperluan Keselamatan } \\
\hline Memperoleh pekerjaan tetap selepas tamat belajar & 4.49 & 0.66 \\
\hline Memperoleh kehidupan yang lebih terjamin pada masa depan & 4.76 & 0.46 \\
\hline Menjadi contoh yang baik kepada adik beradik yang lain & 4.58 & 0.64 \\
\hline $\begin{array}{l}\text { Mengelakkan diri daripada ketinggalan oleh rakan yang } \\
\text { berterusan mencapai kejayaan }\end{array}$ & 4.27 & 0.85 \\
\hline Mengelakkan diri daripada menyusahkan orang lain & 4.46 & 0.69 \\
\hline Keseluruhan Keperluan Keselamatan & 4.51 & 0.42 \\
\hline \multicolumn{3}{|l|}{ Keperluan Sosial } \\
\hline Mengelakkan diri daripada hidup yang membosankan & 3.97 & 0.99 \\
\hline Menyertai pelbagai aktiviti persatuan & 4.00 & 0.83 \\
\hline Berjumpa lebih ramai kawan & 4.06 & 0.80 \\
\hline Ingin diberi perhatian oleh guru & 3.71 & 0.97 \\
\hline Ingin diberi perhatian oleh rakan lain & 3.61 & 0.96 \\
\hline Keseluruhan Keperluan Sosial & 3.87 & 0.66 \\
\hline \multicolumn{3}{|l|}{ Keperluan penghargaan kendiri } \\
\hline Mempertingkatkan keyakinan diri & 4.64 & 0.55 \\
\hline Memperoleh ilmu pengetahuan & 4.69 & 0.52 \\
\hline Dihargai oleh orang lain & 4.22 & 0.79 \\
\hline Dihormati oleh orang lain & 4.32 & 0.71 \\
\hline Mendapatkan anugerah kecemerlangan akademik & 4.72 & 0.51 \\
\hline Keseluruhan Keperluan Estim Kendiri & 4.51 & 0.40 \\
\hline \multicolumn{3}{|l|}{ Keperluan Penyempurnaan Kendiri } \\
\hline Perkembangkan potensi diri & 4.60 & 0.56 \\
\hline Memenuhi impian dan mencapai cita-cita peribadi & 4.70 & 0.54 \\
\hline Memahami kelemahan dan kekuatan diri sendiri & 4.31 & 0.69 \\
\hline Meningkatkan status sosial & 4.41 & 0.72 \\
\hline Mendapatkan harta kekayaan lebih banyak pada masa depan & 3.51 & 1.01 \\
\hline Keseluruhan Keperluan Penyempurnaan Kendiri & 4.30 & 0.41 \\
\hline
\end{tabular}




\section{PERBINCANGAN}

\section{Tahap Motivasi dan Tahap Aspirasi Pelajar Generasi Pertama}

Secara keseluruhannya hasil kajian menunjukkan motivasi pelajar generasi pertama adalah pada tahap tinggi. Hal ini bermakna terdapat dorongan yang kuat terhadap aspirasi melanjutkan pelajaran ke IPT dalam kalangan pelajar generasi pertama di sekolah menengah luar bandar di bahagian Tawau negeri Sabah. Perkara ini berlaku hasil dorongan pelbagai faktor motivasi. Dorongan terpenting dan utama adalah faktor fisiologi. Faktor-faktor lain yang tidak kurang pentingnya adalah keperluan keselamatan, keperluan penghargaan kendiri, keperluan penyempurnaan kendiri dan faktor keperluan sosial. Hasil kajian ini menyokong kajian-kajian lepas yang mendapati pelajar ingin melanjutkan pelajaran ke kolej atau universiti kerana dorongan untuk mendapatkan keperluan fisiologi dan penyempurnaan kendiri (Pope \& Fermin, 2003) serta penghargaan kendiri (Sheek, 2007).

Sehubungan dengan itu, hasil kajian juga mendapati aspirasi pelajar generasi pertama untuk melanjutkan pelajaran ke IPT adalah pada tahap sederhana tinggi. Hal ini bermakna pelajar generasi pertama di sekolah menengah luar bandar bersikap positif terhadap pendidikan dan mereka ingin melanjutkan pelajaran ke IPT. Hasil kajian menunjukkan pelajar generasi pertama mempunyai matlamat yang jelas untuk melanjutkan pelajaran ke IPT. Matlamat tersebut dapat diperhatikan apabila mereka mempunyai perancangan untuk melanjutkan pelajaran ke IPT selepas tamat sekolah menengah. Dalam usaha tersebut, mereka juga menunjukkan kesediaan untuk mengikuti kursus tertentu seperti kursus bahasa Inggeris sebagai persediaan sebelum melanjutkan pelajaran ke IPT. Hasil kajian ini tidak menyokong hasil kajian Saenz et al. (2007) serta Horn dan Nunez (2000). Perkara ini berlaku kerana berkemungkinan respoden dalam kajian ini terdiri daripada pelajar-pelajar luar bandar yang berpencapaian akademik sederhana. Dengan pencapaian akademik sedemikian, mereka juga ada keinginan untuk melanjutkan pelajaran ke IPT.

\section{Hubungan antara Motivasi dan Aspirasi}

Hasil kajian menunjukkan motivasi mempunyai hubungan yang positif dengan aspirasi. Hal ini bermakna jika tahap motivasi 
meningkat maka tahap aspirasi juga meningkat. Sehubungan itu, dapatan kajian ini menunjukkan aspek-aspek motivasi mempunyai hubungan yang positif dengan aspirasi pelajar generasi pertama di sekolah menengah luar bandar.

Dapatan kajian ini menunjukkan aspek keperluan keselamatan mempunyai hubungan yang kuat dengan aspirasi. Faktor ini menunjukkan pelajar generasi pertama yang lebih mengutamakan aspek keperluan keselamatan (contoh: ingin memperoleh pekerjaan tetap selepas tamat pengajian) juga mempunyai tahap aspirasi yang tinggi. Dapatan kajian ini menyokong dapatan kajian Freeman (1999) yang mengutarakan pertimbangan lebih penting bagi pelajar luar bandar untuk melanjutkan pelajaran ke kolej adalah jangkaan mereka untuk memperoleh pekerjaan yang terjamin selepas tamat pengajian kelak.

Sementara itu, aspek keperluan fisiologi mempunyai hubungan dengan aspirasi pada tahap sederhana. Hal ini bermakna aspirasi pelajar generasi pertama akan meningkat jika terdapat peningkatan dalam keperluan fisiologi pelajar. Pelajar ingin melanjutkan pelajaran ke IPT kerana dorongan untuk mendapatkan keperluan fisiologi untuk diri dan keluarga. Antara keperluan tersebut termasuklah keinginan untuk memperoleh pekerjaan yang lebih baik dan bergaji tinggi serta ingin memperbaiki taraf hidup keluarga. Hasil dapatan kajian ini menyokong hasil kajian lain yang mendapati alasan pelajar melanjutkan pelajaran ke universiti adalah kerana ingin membantu keluarga untuk mencapai taraf hidup lebih baik (Gofen, 2009; Engle et al., 2006) dan mendapat pekerjaan yang bergaji tinggi (Pope \& Fermin, 2003; Smith, 2009).

Aspek keperluan sosial juga mempunyai hubungan yang positif dengan aspirasi pada tahap sederhana. Faktor ini menunjukkan aspirasi pelajar generasi pertama untuk melanjutkan pelajaran ke IPT akan meningkat jika terdapat peningkatan keinginan pelajar dalam aspek keperluan sosial. Antara faktor keperluan sosial pelajar ialah keinginan mendapat lebih ramai kawan baru. Pelajar ingin melanjutkan pelajaran ke IPT kerana dorongan untuk mendapat lebih ramai kawan baru apabila melanjutkan pelajaran ke IPT kelak. Penemuan kajian ini mengukuhkan lagi teori keperluan Maslow (1970) bahawa setelah keperluan fisiologi dan keselamatan dipuaskan, maka rasa ingin dikasihi dan mengasihi serta rasa disayangi dan menyayangi menjadi motivasi dalam kehidupan seseorang. 
Aspek keperluan penghargaan kendiri mempunyai hubungan yang positif dengan aspirasi pada tahap sederhana. Ini bermakna aspirasi pelajar generasi pertama akan meningkat jika terdapat peningkatan untuk mendapatkan keperluan penghargaan kendiri. Penemuan ini bermakna pelajar generasi pertama mahu melanjutkan pelajaran kerana ingin meningkatkan kebolehan diri sendiri, pencapaian dan penghormatan diri. Dapatan kajian ini selari dengan dapatan kajian Sheek (2007) yang menunjukkan pelajar mahu melanjutkan pelajaran kerana mahu ibu bapa berbangga dengan mereka.

Keinginan pelajar untuk mendapatkan keperluan penyempurnaan kendiri juga didapati mempunyai pertalian positif dengan aspirasi mereka pada tahap sederhana. Ini bermaksud pelajar yang ingin memenuhi keperluan penyempurnaan kendiri (contoh: mencapai impian dan cita-cita peribadi) juga merupakan pelajar berkeinginan untuk melanjutkan pelajaran ke IPT. Penemuan kajian ini selari dan menyokong teori keperluan Maslow (1970) yang menyatakan pada tahap keperluan pencapaian hasrat diri, manusia ingin mencapai cita-cita dan membuktikan kebolehannya kepada masyarakat. Hasil kajian ini juga menyokong kajian Pope dan Fermin (2003) yang mendapati alasan asas pelajar untuk melanjutkan pelajaran ke kolej adalah untuk mencapai matlamat peribadi dan kerjaya.

Kesimpulannya, aspek keperluan keselamatan mempunyai hubungan yang positif dan kuat dengan aspirasi. Manakala aspek keperluan fisiologi, sosial, penghargaan kendiri dan penyempurnaan kendiri mempunyai hubungan yang positif pada tahap sederhana dengan aspirasi pelajar generasi pertama di sekolah menengah luar bandar.

\section{Faktor-faktor Motivasi Mempengaruhi Aspirasi}

Hasil analisis korelasi pearson menunjukkan bahawa faktor motivasi secara keseluruhan mempunyai hubungan yang positif dengan aspirasi. Ini bermakna jika terdapat peningkatan pada motivasi, maka tahap aspirasi juga meningkat. Perkara tersebut berlaku kerana faktor-faktor motivasi mempengaruhi aspirasi. Terdapat dorongan dalam diri pelajar untuk melanjutkan pelajaran ke IPT. Dorongan tersebut berkait rapat dengan keperluan pelajar iaitu keperluan fisiologi, keperluan keselamatan, keperluan sosial, keperluan penghargaan kendiri dan keperluan penyempurnaan kendiri. 
Hasil kajian mendapati aspek keperluan fisiologi adalah faktor teratas yang mendorong pelajar melanjutkan pelajaran ke IPT. Faktor keperluan fisiologi yang utama adalah keinginan untuk mendapat pekerjaan yang lebih baik selepas menamatkan pengajian. Penemuan ini menyokong hasil kajian oleh Pope dan Fermin (2003) yang mendapati alasan pelajar untuk melanjutkan pelajaran berkait rapat dengan keinginan untuk memperoleh pekerjaan yang lebih baik selepas memperoleh ijazah. Di samping itu, keinginan untuk meningkatkan taraf hidup keluarga juga menjadi alasan utama kepada pelajar untuk melanjutkan pelajaran ke IPT. Penemuan ini sinonim dengan majoriti hasil kajian terdahuluyang mendapati pelajar mahu melanjutkan pelajaran ke kolej untuk memenuhi keperluan keluarga khususnya memperbaiki taraf hidup dan keluar daripada belenggu kemiskinan (Saenz et al. 2007; Smith 2009; Gofen 2009; Smith 2008).

Di samping itu, aspek keperluan keselamatan merupakan faktor kedua terpenting yang turut mendorong pelajar melanjutkan pelajaran ke IPT. Keperluan keselamatan pelajar berkait rapat dengan keinginan untuk mendapatkan kehidupan yang lebih terjamin pada masa depan. Dapatan temu bual menunjukkan pelajar generasi pertama ingin memperoleh pekerjaan yang tetap selepas tamat pengajian. Dapatan ini tidak menghairankan kerana tinjauan literatur mendapati pelajar mahu melanjutkan ke IPT kerana keperluan keselamatan khususnya untuk mendapatkan pekerjaan yang terjamin. Hasil kajian ini secara tidak langsung menyokong hasil kajian Burnell (2003) yang mendapati pelajar tidak akan melanjutkan pelajaran ke kolej jika mereka beranggapan tindakan tersebut tidak menjanjikan kehidupan yang lebih baik pada masa akan datang.

Aspek keperluan penghargaan kendiri juga merupakan faktor pendorong kepada pelajar generasi pertama untuk melanjutkan pelajaran ke IPT. Menurut Maslow (1970) setelah manusia berjaya memuaskan keperluan-keperluan mereka dan diri mereka juga diterima oleh orang lain, manusia sebenarnya suka dihargai, dihormati, dan disanjung oleh orang lain. Dapatan kajian ini menunjukkan pelajar generasi pertama bertindak melanjutkan pelajaran ke IPT kerana ingin mendapatkan anugerah kecemerlangan akademik semasa melanjutkan pelajaran di IPT kelak. Mereka berbuat demikian untuk mendapatkan penghormatan dan disanjung tinggi. Dapatan kajian ini selari dengan kajian Sheek (2007) yang 
menunjukkan pelajar ingin ibu bapa berbangga dengan mereka. Ini menunjukkan bahawa dorongan pelajar untuk melanjutkan pelajaran ke IPT berkait rapat dengan keperluan penghormatan diri iaitu ingin disanjung oleh orang lain khususnya oleh ibu bapa.

Seterusnya, pelajar juga mahu melanjutkan pelajaran ke IPT kerana dorongan keperluan penyempurnaan kendiri. Untuk memenuhi keperluan penyempurnaan kendiri pelajar mahu merealisasikan impian dan cita-cita mereka. Penemuan ini selari dengan hasil kajian Pope dan Fermin (2003) yang mendapati alasan asas pelajar untuk melanjutkan pelajaran ke kolej adalah untuk mencapai matlamat peribadi dan kerjaya khususnya untuk memperoleh ijazah. Smith $(2008,2009)$ pula mendapati seseorang pelajar ingin melanjutkan pelajaran ke kolej untuk meningkatkan mobiliti sosial.

Faktor terakhir yang mendorong pelajar untuk melanjutkan pelajaran ke IPT adalah aspek keperluan sosial. Peserta kajian yang ditemu bual menyatakan mereka ingin melanjutkan pelajaran ke IPT bagi membolehkan mereka mendapat lebih ramai kawan baru. Ini bermakna pelajar generasi pertama ingin memenuhi keperluan persahabatan yang ada rasa dipunyai dan mempunyai, dikasihi dan mengasihi serta rasa disayangi dan menyayangi. Penemuan kajian ini menyokong teori keperluan Maslow (1970) bahawa setelah keperluan fisiologi dan keselamatan dipuaskan, maka rasa ingin dikasihi dan mengasihi serta rasa disayangi dan menyayangi menjadi motivasi dalam kehidupan seseorang. Namun demikian, hasil temu bual dengan peserta kajian juga mendapati faktor mendapatkan kawan baru bukanlah faktor utama yang mendorong mereka untuk melanjutkan pelajaran ke IPT. Perkara ini berlaku barangkali kerana pelajar sudah pun mempunyai ramai kawan semasa menuntut di peringkat sekolah menengah. Justeru, faktor tersebut bukanlah menjadi keutamaan mereka apabila melanjutkan pelajaran ke IPT kelak.

\section{KESIMPULAN IMPLIKASI DAN CADANGAN}

Secara keseluruhannya hasil kajian menunjukkan bahawa motivasi pelajar generasi pertama adalah pada tahap tinggi. Sehubungan itu, pelajar generasi pertama juga mempunyai aspirasi untuk 
melanjutkan pelajaran ke IPT pada tahap sederhana tinggi. Perkara ini tidak menghairankan kerana hasil kajian mendapati motivasi berhubungan secara positif dengan aspirasi. Didapati pelajar yang bermotivasi juga mempunyai aspirasi untuk melanjutkan pelajaran ke IPT. Faktor motivasi yang dominan dalam mendorong pelajar melanjutkan pelajaran ke IPT adalah aspek keperluan fisiologi dan keperluan keselamatan. Aspek keperluan fisiologi adalah faktor teratas berbanding faktor keperluan keselamatan, keperluan sosial, keperluan penghargaan kendiri dan keperluan penyempurnaan kendiri. Aspek keperluan fisiologi yang menjadi faktor utama adalah keinginan pelajar untuk mendapat pekerjaan yang lebih baik selepas menamatkan pengajian. Sementara aspek keperluan keselamatan dan penghargaan kendiri merupakan faktor kedua terpenting yang turut mendorong pelajar untuk melanjutkan pelajaran ke IPT. Bagi aspek keperluan keselamatan, pelajar ingin menikmati kehidupan yang lebih terjamin pada masa depan dengan memperoleh pekerjaan yang tetap selepas tamat pengajian. Manakala untuk memenuhi keperluan penghargaan kendiri, mereka ingin melanjutkan pelajaran ke IPT untuk mendapat anugerah kecemerlangan akademik dan ilmu pengetahuan.

Hasil kajian ini memberi implikasi kepada pelajar, pihak sekolah dan IPT. Hasil kajian jelas menunjukkan pelajar yang bermotivasi juga mempunyai aspirasi untuk melanjutkan pelajaran ke IPT. Sehubungan itu, adalah perlu kepada setiap pelajar meningkatkan motivasi kendiri masing-masing bagi mempertingkatkan aspirasi melanjutkan pelajaran ke IPT. Rajah 1 menunjukkan strategi yang boleh digunakan oleh pelajar untuk meningkatkan aspirasi melanjutkan pelajaran ke IPT. Pelajar perlu meningkatkan keinginan untuk mendapatkan keperluan fisiologi (pekerjaan lebih baik), keperluan keselamatan (masa depan terjamin, pekerjaan tetap), keperluan penghargaan kendiri (anugerah kecemerlangan akademik, mendapatkan ilmu pengetahuan), keperluan penyempurnaan kendiri (mencapai impian dan cita-cita) dan keperluan sosial (mendapat lebih ramai kawan baru). Jika semua keperluan tersebut tersemat dalam diri pelajar, maka ia akan menjadi pendorong kepada aspirasi untuk melanjutkan pelajaran ke IPT. Bagaimanapun, aspirasi pelajar hanya dapat dipertingkatkan sekiranya pelajar mempunyai matlamat dan kesediaan untuk melanjutkan pelajaran ke IPT. 


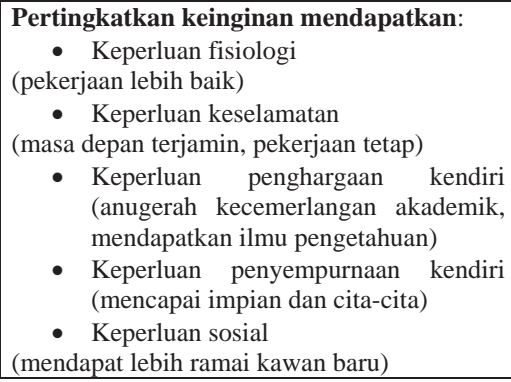

- Keperluan penghargaan kendiri (anugerah kecemerlangan akademik, mendapatkan ilmu pengetahuan)

- Keperluan penyempurnaan kendiri (mencapai impian dan cita-cita)

- Keperluan sosial

(mendapat lebih ramai kawan baru)

Rajah 1. Strategi Meningkatkan Aspirasi Melanjutkan Pelajaran ke IPT

Bagi memastikan aspirasi pelajar generasi pertama untuk melanjutkan pelajaran ke IPT dapat dikekalkan atau dipertingkat dan seterusnya direalisasikan, maka pihak sekolah haruslah memberikan motivasi atau dorongan yang berterusan kepada pelajar. Untuk tujuan tersebut, pihak sekolah melalui unit bimbingan dan kaunseling perlu memberi fokus kepada program-program yang boleh meningkatkan motivasi dan aspirasi pelajar untuk melanjutkan pelajaran ke IPT. Umpamanya, dicadangkan kepada kaunselor sekolah supaya mengadakan program "Jom Masuk U" di sekolah masing-masing. Program ini mempunyai objektif serampang dua mata iaitu mendedahkan peluang-peluang belajar di IPT dan peluang kerjaya kepada para pelajar. Implikasi kedua, pihak sekolah perlu memberikan pendedahan kerjaya yang meluas kepada pelajar. Perkara ini perlu dilakukan kerana pelajar luar bandar hanya terdedah dengan pekerjaan ibu bapa dan pekerjaan lain yang ada di persekitaran mereka. Bagi tujuan tersebut, dicadangkan kepada pihak sekolah mengadakan dasar 'Satu Pelajar Satu Kerjaya (1P1K) yang mana dasar tersebut dapat membantu pelajar mempunyai matlamat pendidikan dan kerjaya yang jelas. Matlamat tersebut penting bagi memastikan hasrat pelajar untuk mendapat pekerjaan yang lebih baik dan terjamin pada masa depan dapat direalisasikan.

Motivasi dan aspirasi pelajar untuk melanjutkan pelajaran ke IPT adalah satu proses perkembangan diri pelajar. Ia bermula di sekolah dan berterusan sehingga pelajar berjaya melanjutkan pelajaran ke IPT. Oleh sebab itu, bagi memastikan pelajar berjaya melanjutkan 
pelajaran ke IPT maka perlu ada kesinambungan dan penyelarasan antara sekolah menengah dan IPT. Justeru, bagi meningkatkan kebarangkalian pelajar yang bermotivasi dan beraspirasi berjaya melanjutkan pelajaran ke IPT, maka pihak IPT perlu meningkatkan akses pelajar generasi pertama untuk memasuki IPT. Pihak IPT perlu memastikan agar bidang pengajian yang ditawarkan oleh IPT masing-masing releven dan memenuhi permintaan pasaran pekerjaan. Perkara ini penting bagi menarik minat lebih ramai pelajar generasi pertama untuk melanjutkan pelajaran ke IPT. Hasil kajian ini telah membuktikan bahawa pelajar generasi pertama hanya akan melanjutkan pelajaran ke IPT jika mereka merasakan tindakan sedemikian memberikan pulangan khususnya mereka memperoleh pekerjaan selepas tamat pengajian. Bagi memastikan hasrat tersebut menjadi kenyataan, Bahagian Pembangunan Pelajar di IPT perlu memberikan pendedahan kerjaya yang berterusan kepada pelajar generasi pertama yang berjaya melanjutkan pelajaran ke IPT.

Kajian ini telah memberi tumpuan kepada pelajar generasi pertama yang sedang menuntut di tingkatan empat di sekolah menengah luar bandar sebagai sampel kajian tanpa meneliti perbezaan mereka mengikut etnik. Oleh itu, kajian ini juga mencadangkan agar pada masa akan datang kajian terhadap pelajar generasi pertama mengambil kira perbezaan etnik. Kajian lanjutan juga disyorkan menggunakan sampel yang lebih besar dengan melibatkan pelajar generasi pertama di bandar. Dapatan kajian seumpama ini dapat memberikan maklumat yang lebih terfokus kepada pihak-pihak tertentu seperti Kementerian Pelajaran Malaysia, Kementerian Pengajian Tinggi dan Kementerian Sumber Manusia bagi merangka dasar yang dapat membantu pelajar-pelajar generasi pertama melanjutkan pelajaran ke IPT dan seterusnya menambah bilangan pelajar berkelulusan tertiari yang secara langsung dapat menambahkan bilangan tenaga kerja dalam usaha memenuhi keperluan Model Baru Ekonomi Malaysia.

\section{RUJUKAN}

Azizi Yahaya, Shahrin Hashim, Jamaludin Ramli, Yusof Boon \& Abdul Rahim Hamdan. (2009). Menguasai penyelidikan dalam pendidikan: Teori, analisis, \& interpretasi data. Kuala Lumpur: PTS Professional. 
Burnell, B. A. (2003). The "Real World" aspirations of work-bound rural students. Journal of Research in Rural Education, 18(2), 104-113.

Ceja, M. A. (2001). Applying, choosing, and enrolling in higher education: understanding the college choice process of first-generation Chicana students (Unpublished doctoral dissertation). University of California, Los Angeles.

Choy, S. P. (2001). Students whose parents did not go to college. Washington: National center for Education Statistics.

Chwan-Yi Chiang. (2001). Using Maslow's theory to explain nontraditional students' motivation for continuing education in Taiwan (Unpublished dotoral dissertation). University of South Dakota.

Creswell, J.W., \& Plano Clark, V. L.(2011). Designing and conducting mixed methods research. Ed. Ke-2. California: Sage Publications, Inc.

Engle, J., Bormeo, A., \& O'Brien, C. (2006). Straight from the source: what works for first-generation college students. Texas: The Pell Institute for the Study of Opportunity in Higher Education.

Freeman, K. (2005). African Americans and college choice: The influence of family and school. Albany: SUNY Press.

Freeman, K. (1999). The race factor in African-American college choice. Urban Education, 34(1):4-25.

Gofen, A. (2009). Family capital: How first-generation higher education students break the intergenerational cycle. Family Relations, 58(1), 104-120.

Grieve, K. A. (2009). Urban American male high school students educational aspirations for college and the influence offamily, school, and peers. (Unpublished doctoral dissertation). The University of Toledo.

Halimah Harun. (2006). Minat, motivasi dan kemahiran mengajar guru. Jurnal Pendidikan, 31, 83-96

Horn, L., \& Nunez, A. M. (2000). Mapping the road to college: First-generation students' match track, planning strategies, and context of support. Washington: National Center for Education Statistics.

Ishitani, T. T. (2003). A longtudinal approach to assesing attention behavior among first generation students: Time-varying effects of pre-college characteristics. Research in Higher Education, 44(4), 433-449. 
Jabatan Pengajian Tinggi. (2009). Data permohonan dan penawaran bagi kemasukan program pengajian lepas SPM / setaraf sesi 2008/2009, Putrajaya.

Joseph, F. H., Earl, B., \& Frued, H. (1997). Explaining social issues. London: Pine Forge Press.

Jui-Mei Yien. (2004). Motivational factors affecting Amway Taiwan distributors intentions to participate in continuing education. (Unpublished doctoral dissertation). University of South Dakota.

Kementerian Pengajian Tinggi Malaysia. (2008). Pelan Strategik Pengajian Tinggi Negara Melangkaui Tahun 2020. Kuala Lumpur: Kementerian Pengajian Tinggi Malaysia.

Lim Kong Teong \& Tang Swee Mei, (2005). Perhubungan antara prinsip-prinsip TQM, kepuasan hati staf, kepuasan hati pelajar dan pencapaian akademik pelajar: Satu kerangka konseptual. Malaysian Journal of Learning and Instruction (MJLI), 2, $1-16$.

Maslow, A. H. (1970). Motivation and personality (2 ed.). New York: Harper \& Row Publishers.

Mcinerney, D. M., (2006). The motivational profiles and perceptions of schooling of Asian students in Australia. Malaysian Journal of Learning and Instruction (MJLI), 3, 1-31.

Mohd. Firdaus Abdul Salam. (2003). Sikap dan motivasi pembelajaran Bahasa Inggeris serta implikasinya terhadap pencapaian: Satu analisis di kalangan pelajar sekolah menengah pedalaman Sabah. Tesis Ijazah Sarjana Pendidikan Yang Tidak Diterbitkan. Universiti Kebangsaan Malaysia, Bangi.

Noor Fitriyati Abdul Samad. (2009). Hubungan motivasi dan pembelajaran kendiri. Kertas projek ijazah sarjana sains, Universiti Utara Malaysia, Sintok.

Norliza Abdul Majid. (2011). Kemahiran komunikasi dan motivasi kerja dalam kalangan guru cemerlang. Tesis Ijazah Doktor Falsafah, Universiti Kebangsaan Malaysia, Bangi.

Nunally, J., \& Bernstein, I. (1994). Psychometric theory. Edisi ke-3. New York: McGraw Hill.

Patton, M. Q. (1990). Qualitative evaluations and research methods. Newburry Park, California: Sage Publications.

Peters, P. A. (2009). Inspired to be the first: Factors that predispose African American and Mexican American first-generation students to pursue higher education. (Unpublished doctoral dissertation). Cardinal Strich University. 
Pope, M. L., \& Fermin, B. (2003). The perceptions of college students regarding the factors most influential in their decision to attend postsecondary education. College and University, 78(4), 19-25.

Saemah Rahman. (2004). Hubungan antara metakognisi, motivasi dan pencapaian akademik pelajar universiti. Tesis Ijazah Doktor Falsafah, Universiti Malaya, Kuala Lumpur.

Saenz, V., B., Hurtado, S., Barrera, D., Wolf, D., \& Yeung, F.(2007). First in my family: a profile of first-generation college students at four-year institutions since 1971. Washington: The Foundation for Independent Higher Education.

Sheek, J. L. (2007). Rural students, aspiration, motivation, and music education: Why don't more rural students make it to college? Thesis degree doctor of education, University of North Carolina, Greensboro.

Smith, M. J. (2008). College choice process of first generation black female students: Encouraged to what end? The Negro Educational Review, 59(3-4), 147-237.

Smith, M. J. (2009). Right direction, wrong maps: Understanding the involvement of low-SES African American parents to enlist them as partners in college choice. Education and Urban Society, 41(2), 171-196.

Syed Mohamad Syed Abdullah. (2010). Keberkesanan modul merancang kerjaya ke atas motivasi belajar, kemahiran belajar dan kebolehan merancang kerjaya dalam kalangan pelajar berpencapaian rendah. Tesis Ijazah Doktor Falsafah Yang Tidak Diterbitkan. Universiti Kebangsaan Malaysia, Bangi.

Terenzini, P., Cabrera, A., \& Bernal, E. (2001). Swimming against the tide: The poor in American higher education. Princeton, NJ: College Board.

Terenzini, P. T., Springer, L., Yaeger, P. M., Pascarella, E. T., \& Nora, A.(1996). First-generation college students: Characteristics, experiences, and cognitive development. Research in Higher Education, 37, 1-22.

York-Anderson, D. C., \& Bowman, S.L. (1991). Assessing the college knowledge of first-generation and second-generation college students. Journal of College Student Development, $32,116-122$.

Zaharah Mohd. Nadzir, (2009). Hubungan antara persepsi pelajar tentang persekitaran sekolah, motivasi akademik dan strategi pembelajaran dengan pencapaian dalam mata pelajaran sains. Tesis Ijazah Doktor Falsafah Yang Tidak Diterbitkan. Universiti Kebangsaan Malaysia, Bangi. 
Zuaini Ishak, Nor Aziah Abdul Manaf \& Rosliza Mat Zin, (2008). Faktor penentu prestasi pelajar matrikulasi dalam subjek perakaunan. Malaysian Journal of Learning and Instruction (MJLI), 5, 99-115. 